\title{
Risk Factors for 28-day Mortality Among COVID-19 Patients in an Intensive Care Unit of a Tertiary Care Center in Istanbul
}

\section{İstanbul'daki Üçüncü Basamak bir Merkezin Yoğun Bakım Ünitesindeki COVID-19 Hastalarında 28 Günlük Mortalite için Risk Faktörleri}

\author{
Ahmet Tolga Erol ${ }^{1 \oplus}$, Sinan Aşar ${ }^{1 \oplus}$, Mehmet Süleyman Sabaz ${ }^{2}$, Beyza Ören Bilgin ${ }^{1 \oplus}$, Zafer Çukurova ${ }^{1 \oplus}$ \\ ${ }^{1}$ University of Health Sciences Bakirkoy Dr. Sadi Konuk Training and Research Hospital, Department of Anesthesiology and Reanimation, \\ Istanbul, Turkey \\ ${ }^{2}$ Marmara University Pendik Training and Research Hospital, Department of Anesthesiology and Reanimation, Istanbul, Turkey
}

Received: 12.01.2021 / Accepted: 30.03.2021 / Published Online: 31.03.2021

Cite as: Erol AT, Aşar S, Sabaz MS, Ören Bilgin B, Çukurova. Risk factors for 28-day mortality among COVID-19 patients in an intensive care unit of a tertiary care center in Istanbul. Med J Bakirkoy 2021;17(1):100-7.

\section{ABSTRACT}

Objective: In late 2019, the Coronavirus disease 2019 (COVID-19) has been pandemic worldwide, starting in Wuhan, China. In this study, we aimed to evaluate the factors associated with 28-day outcomes in patients admitted to the intensive care unit with the diagnosis of COVID-19. Method: This study has a retrospective cohort design. COVID-19 patients identified according to World Health Organization guidelines are included. Patient data were recorded to a centralized system utilizing ImdSoft-Meta vision/Qlin/CU Clinical Decision Support Software. Individual datasets about required parameters were obtained from Structured Query Language (SQL) queries. The main laboratory parameters were examined. SOFA, APACHE II, and Charlson Comorbidity Score (CCS) were calculated. In evaluating laboratory parameters and disease risk scores, which are thought to affect 28-day mortality, logistic analysis were performed using the Backward LR model.

Results: The study was carried out with 101 patients, 40 (39.6\%) of whom were women, and 61 (60.4\%) of men, who met the inclusion criteria. The ages of the patients ranged from 21 to 88 , and the mean age was $58.45 \pm 15.41$ years. The mean intensive care hospitalization period was $12.5 \pm 10.2$ days. The all-cause in-hospital mortality rate was $61.4 \%$. Leukocyte count, CK, NT-proBNP, PCT, CRP, ferritin, neutrophil count and percentage, D-Dimer, LDH, AST values were found to be significantly higher in non-survivors. The lymphocyte count and percentage, and platelet count values were found to be significantly low in non-survivors. The lymphocyte percentage, LDH, and CCS were significant in the 28-day mortality in multivariate analysis ( $p$ values are $0.01,0.003,0.008$, respectively).

Conclusion: High lymphocyte values have been found to significantly reduce the risk of death in patients diagnosed with COVID-19. Lymphocyte percentage, $L D H$, and CCS were evaluated as the most successful parameters in predicting 28-day mortality in the intensive care unit.

Keywords: COVID-19, Charlson Comorbidity Score, Mortality, Risk factors, SARS-CoV-2

öz

Amaç: 2019 sonlarında, Çin'in Hubei eyaletinin Wuhan şehrinde başlayıp 2020 yılının ilk altı ayında tüm Dünyada Covid-19 pandemisi salgın olarak yaşanmaktadır. Bu çalışmada, yoğun bakım ünitesine COVID-19 tanısıyla başvuran hastalarda 28 günlük sonuçlarla ilişkili faktörlerin değerlendirilmesi amaçlanmıştır.

Yöntem: Bu çalıșma retrospektif kohort olarak tasarlandı. Dünya Sağlık Örgütü kılavuzlarına göre tanımlanan COVID-19 hastaları hastalar çalışmaya dahil edildi. Hasta verileri, ImdSoft-Meta vision / QlinICU Clinical Decision Support Software kullanılarak merkezi bir sisteme kaydedildi. Structured Query Language (SQL) sorgularından gerekli parametrelerle ilgili bireysel veri kümeleri elde edildi. Ana laboratuvar parametreleri incelendi. SOFA, APACHE II ve Charlson Komorbidite Skoru (CCS) hesaplandı. 28 günlük mortaliteyi etkilediği düşünülen laboratuvar parametreleri ve hastalık risk skorlarının değerlendirilmesinde Backward LR modeli kullanılarak lojistik analiz yapıldı.

Bulgular: Çalışma, dahil edilme kriterlerini karşılayan 40'ı $(\%$ 39,6) kadın ve 61'i $(\%$ 60,4) erkek olmak üzere 101 hasta ile gerçekleştirildi. Hastaların yașları 21 ile 88 arasında değișmekte olup, ortalama yaș 58,45 $\pm 15,41$ yıldı. Ortalama yoğun bakıma yatıs süresi $12,5 \pm 10,2$ gündü. Tüm nedenlere bağlı hastane içi ölüm oranı\% 61,4'tü. Hayatta kalmayanlarda lökosit sayıII, CK, NT-proBNP, PCT, CRP, ferritin, nötrofil sayısı ve yüzdesi, D-Dimer, LDH, AST değerleri anlamlı olarak yüksek bulundu. Hayatta kalmayanlarda lenfosit sayısı ve yüzdesi ile trombosit sayısı değerleri anlamlı olarak düşük bulundu. Lenfosit yüzdesi, LDH ve CCS, çok değişkenli analizde 28 günlük mortalitede anlamlıydı ( $p$ değerleri sırasıyla 0,01, 0,003, 0,008'dir).

Sonuçlar: Yüksek lenfosit değerlerinin COVID-19 teşhisi konan hastalarda ölüm riskini önemli ölçüde azalttığı görüldü. Yoğun bakım ünitesinde 28 günlük mortaliteyi öngörmede en başarılı parametreler lenfosit yüzdesi, LDH ve CCS olarak değerlendirildi.

Anahtar kelimeler: Şiddetli COVID-19, Mortalite, Risk faktörleri, YBÜ hastaları

Corresponding Author:

drtolgaerol@gmail.com
A.T. Erol 0000-0001-6108-8550

S. Aşar 0000-0001-5787-5885
M.S. Sabaz 0000-0001-7034-0391

B. Ören Bilgin 0000-0002-5964-5650
Z. Çukurova 0000-0002-5078-315X

(c) Telif hakkı Sağılık Bilimleri Üniversitesi Bakırköy Dr. Sadi Konuk Eğitim ve Araştırma Hastanesi’ne aittir. Logos Tıp Yayıncılık tarafindan yayınlanmaktadır. Bu dergide yayınlanan bütün makaleler Creative Commons Atff-GayriTicari 4.0 Uluslararası Lisansı ile lisanslanmıştır.

(c) Copyright Health Sciences University Bakırköy Sadi Konuk Training and Research Hospital. This journal published by Logos Medical Publishing.

Licenced by Creative Commons Attribution-NonCommercial 4.0 International (CC BY) 


\section{INTRODUCTION}

At the end of 2019, several cases of pneumonia of unknown etiology were reported in Wuhan city of Hubei province, China ${ }^{(1,2)}$. The cause of the disease was identified as a novel Coronavirus strain (2019$\mathrm{nCoV}$ ) that has not previously been detected in humans. Later, the 2019-nCoV disease was named Coronavirus disease-2019 (COVID-19), and the virus was named as SARS-CoV-2 because of its close resemblance to the Coronavirus (SARS-CoV) associated with Severe Acute Respiratory Disorder Syndrome. There have been more than one hundred fifteen million patients with confirmed with COVID19 worldwide by the end of February $2021^{(3)}$

The spectrum of COVID-19 varies from mild and severe to critical. Reports from China, Italy, and the US series show a mortality rate between 60 and $85 \%$ among ICU (Intensive Care Unit) patients ${ }^{(4-6)}$. In a single-center Swedish study evaluating the clinical characteristics and outcomes of COVID-19 patients in ICU, the in-hospital mortality rate was $23.9 \%$, and the median ICU stay was 14 days. Older age and admission from the emergency department was associated with high mortality rates. Another study was performed in two centers in New York City, with 257 critically ill COVID-19 patients ${ }^{(7)}$. The mortality rate was $39 \%$, and older age, chronic cardiac disease, chronic lung disease, and higher D-dimer levels were independently associated with mortality.

Although there are many biomarkers that can be used to diagnose and monitor sepsis due to bacteria, viruses, and other causes in the intensive care unit, none of them have sufficient sensitivity or specificity for routine use in the clinical practice alone. Although procalcitonin (PCT) and C-reactive protein (CRP) are the most widely used biomarkers, they have limited efficacy in determining the prognosis of sepsis. Various scoring systems such as Acute Physiology and Chronic Health Evaluation Score (APACHE) and Sequential Organ Failure Assessment Score (SOFA) are used for the estimation of mortality in intensive care units. In addition to these scoring systems, many biomarkers are also used to predict prognosis. Previous studies were suggested that some of the hematologic and immunologic variations could serve as predictors for recovery, or they were associated with fatal outcome ${ }^{(8,9)}$.

It is crucial to determine critical outcomes and associated factors in COVID 19 patients in the intensive care unit. These factors are essential for future medical resource planning in the ICU. In this study, we aimed to evaluate the clinical characteristics and laboratory parameters associated with 28-day mortality among COVID-19 patients in an intensive care unit of a tertiary care center in Istanbul, Turkey.

\section{METHOD}

\section{Study population}

This study has a retrospective cohort design. We included patients with COVID-19 who received mechanical ventilation at some point of their ICU stay. The study was performed in the Department of Intensive Care Unit, Health Sciences University Bakırköy Dr. Sadi Konuk Training and Research Hospital (Istanbul, Turkey). Our ICU served as a COVID-19 cohort unit when this study was conducted. The study period started with the first confirmed patient in our hospital on March 18, 2020, and included patients hospitalized until May 07, 2020. COVID-19 diagnosis was made using the Turkish COVID-19 guideline ${ }^{(10)}$.

Patients with the following conditions were excluded: not intubated during their ICU stay, non-sedated patients and those who had missing data. All data structured in the Meta vision/QlinICU Clinical Decision Support Software with the approval of the Ethical Committee of the Health Sciences University Bakırköy Dr. Sadi Konuk Training and Research Hospital was obtained with the queries of the structured query language.

Data obtained on PCT, fibrinogen, ferritin, troponin I, creatine kinase (CK), lactate dehydrogenase (LDH), aspartate aminotransferase (AST), alanine aminotransferase (ALT), d-dimer, leukocyte count, lymphocyte count, neutrophil count, neutrophil percentage, C-reactive protein (CRP), platelet count levels, SOFA, APACHE II, and Charlson Comorbidity Score (CCS) were evaluated. In order to represent the dynamic course of the ICU stay, the median values of the parameters recorded consecutively (except the CCS) were calculated and analyzed. APACHE II disease risk 
score was calculated to predict mortality during admission to intensive care and discharge.

\section{Data analysis}

Means, SDs, medians, interquartile ranges (IQRs), counts, and percentages were used to summarize descriptive statistics. The Kolmogorov-Smirnov test was used to determine if continuous variables had a normal distribution. The Student's t-test was used to compare normally distributed continuous variables, while the Mann-Whitney U-test was used to evaluate skewed results. The $\mathrm{x} 2$-test or Fisher's exact test is used to determine categorical parameters, as applicable. Backward LR model and analysis were used to evaluate the risks of laboratory parameters thought to have an impact on survival. The independent predictors of COVID-19 patients' 28-day mortality were identified using multivariable logistic regression analysis. We included eleven independent variables in our multivariable regression model that we considered relevant to 28 -day mortality. We included only laboratory parameters that have been associated with poor clinical outcomes among patients with COVID-19. The results were given as odds ratios (ORs) with a 95\% confidence interval (CI). SPSS 22.0 was used to conduct the data analysis. Statistical significance was described as a $P$ value of less than 0.05 .

\section{RESULTS}

Of 101 eligible patients, the mean age was $58.4 \pm$ 15.4 years, and $60.4 \%$ of them were male. The mean ICU stay was $12.5 \pm 10.2$ days. In-hospital mortality occurred in 62 patients (61.4\%). The 28-day mortality rate was $54.5 \%$. Patient characteristics are shown in Table 1.

The results of the univariate statistical analysis performed between the non-survival and survival patient groups regarding the measured laboratory parameters, which were thought to be related to COVID-19 disease, were obtained as in Table 1.

There is no significant difference between non-survival patients and survival patients in terms of gender, comorbid disease status, and length of hospital stay. Univariable and multivariable analyses for the 28-day mortality follow-up are presented in Table 2.
Table 1. General characteristics of patients

\begin{tabular}{|c|c|}
\hline & Study population $(n=101)$ \\
\hline Age, years, mean \pm SD & $58.4 \pm 15.4$ \\
\hline Gender, Male, n (\%) & $61(60.4)$ \\
\hline $\begin{array}{l}\text { Length of Hospital Stay, days, } \\
\text { mean } \pm \text { SD }\end{array}$ & $12.5 \pm 10.2$ \\
\hline \multicolumn{2}{|l|}{ Comorbidities } \\
\hline$\geq 1$ comorbidity & $55(54.5)$ \\
\hline $\begin{array}{l}\text { Number of comorbidities, } \\
\text { median (IQR) }\end{array}$ & $1(0-2)$ \\
\hline Hypertension, n (\%) & $31(30.7)$ \\
\hline Diabetes mellitus, n (\%) & $25(24.8)$ \\
\hline Cardiac diseases, n (\%) & 15 (14.9) \\
\hline Renal failure, n (\%) & 12 (11.9) \\
\hline $\begin{array}{l}\text { Chronic obstructive pulmo- } \\
\text { nary disease, n (\%) }\end{array}$ & $16(15.8)$ \\
\hline Cancer, n (\%) & $6(5.9)$ \\
\hline $\begin{array}{l}\text { Charlson Comorbidity Score, } \\
\text { median (IQR) }\end{array}$ & $3(2-5)$ \\
\hline $\begin{array}{l}\text { APACHE score on presentation, } \\
\text { median (IQR) }\end{array}$ & $21(17-30)$ \\
\hline $\begin{array}{l}\text { SOFA score on presentation, } \\
\text { mean } \pm \text { SD }\end{array}$ & $8.9 \pm 4.2$ \\
\hline In-hospital mortality, n (\%) & $62(61.4)$ \\
\hline 28-day mortality, n (\%) & $55(54.5)$ \\
\hline
\end{tabular}

Leucocyte median, leucocyte percentage, neutrophil percentage, CRP, PCT, ferritin, AST, LDH, APACHE-II, CCS were included in the multivariable model.

Among the laboratory values, the lymphocyte percentage (OR:0.436, 95\%Cl: 0.232-0.818), PCT median (OR: 1.487, 95\%Cl: 1.039-2.128), and LDH (OR: $1.015,95 \% \mathrm{Cl}: 1.005-1.025) \quad$ were independently associated with 28-day mortality

\section{DISCUSSION}

Given the lack of definitive treatment and vaccine despite recent advances, rapid and reliable biomarkers are needed to determine the mortality risk early in COVID-19 cases. In this case, it is crucial to make timely and correct decisions regarding the choice of therapeutic approach and to recognize patients at high risk of death at an early stage. In this study, the relationship between laboratory parameters and disease scores (SOFA, APACHE II, CCSs), which were determined as influential factors for the prognosis of COVID-19 disease, with both intensive care and 28-day intensive care mortality was investigated. 
As the strength of the study, it can be said that all of the patients must have received mechanical ventilator support in some of their treatments, and the collected data are recorded by the computer system in an uninterrupted manner with the recording system.

In studies conducted in China, a slight difference was found in the laboratory findings of critical patients who were followed up in the intensive care unit with the diagnosis of COVID-19 compared to those who had a milder disease. PCT levels and lymphopenia are the primary differences.

In this study, PCT was found to be significantly higher in non-survival patients. In the study by Wang $D$ et al., where the data of a total of 138 patients were analyzed, the median laboratory values of the patients who were followed in the intensive care unit and department ward were compared. PCT values greater than $0.05 \mathrm{ng} / \mathrm{mL}$ were found in $49 \%$ of the total number of patients ${ }^{(11)}$. PCT values were not found to be associated with intensive care mortality. However, the ability to predict 28-day intensive care mortality was found to be statistically significant. As with bacterial infections, PCT would be useful in determining the prognosis of COVID-19 virus infection, when evaluated together with patients' clinical statuses and other laboratory parameters.

CRP values were significantly higher in non-survival patients in terms of sensitivity and specificity compared to survival patients. The study by Matsumoto et al. similarly showed high CRP levels in severe pneumonia ${ }^{(12)}$. In the study by Xiaochen Li et al., including 540 patients with COVID-19, 36.6\% of severe patients were found to have a CRP value of $>$ $100 \mathrm{mg} / \mathrm{L}$. However, it is known that the CRP level is not specific for infection, and this level will increase in other inflammatory processes ${ }^{(13)}$. It is suggested that using CRP with other clinical parameters such as PCT and serial measurements may be beneficial.

Leukocyte (WBC) count was found higher in nonsurvival patients compared to survival patients. In the comparison of survival and non-survival patients in the study by Deng et al., increased leukocyte count and decreased lymphocyte count were associated with mortality in the survival group ${ }^{(14)}$. However, in this study, the decrease in lymphocyte values was not associated with both intensive care mortality and 28-day mortality.

It was determined that the lymphocyte count and rate values of non-survival patients were significantly lower than that of survival patients. However, the percentage of lymphocytes was associated with mortality. With a one-unit increase in the percentages of lymphocytes, this study found that the risk of intensive care mortality was reduced by $43.4 \%$ in the patient population diagnosed with COVID-19, and the ability of low lymphocyte percentage to predict 28-day intense mortality was high (Table 2). In a way to support the results of this study, another study revealed that the percentage of blood lymphocytes among all laboratory parameters was the most significant and consistent parameter that showed the progression of the disease ${ }^{(15)}$ whose infection can be asymptomatic or lead to the coronavirus disease 2019 (Covid-19. The low absolute value of lymphocytes can be used in the clinic to diagnose new coronavirus infections or to predict the clinical course because the current distinguishing feature of SARSCoV-2 pathogenesis is the cytokine storm ${ }^{(15)}$ whose infection can be asymptomatic or lead to the coronavirus disease 2019 (Covid-19. This cytokine release syndrome in COVID-19 patients was found to be associated with decreased lymphocyte count ${ }^{(15)}$ whose infection can be asymptomatic or lead to the coronavirus disease 2019 (Covid-19. Lymphopenia was found to be present in more than $80 \%$ of patients at the beginning of the disease ${ }^{(16)}$. Some studies have shown that a significant reduction in total lymphocyte count causes the coronavirus to consume many immune cells and inhibit the cellular immune function of the body. Damage of T lymphocytes was stated as an essential factor leading to exacerbation of the disease ${ }^{(16)}$. Lymphopenia was associated with a significant reduction in $\mathrm{T}$ cells (especially CD8), and this significant reduction of the $\mathrm{T}$ lymphocyte subset was shown to correlate positively with in-hospital mortality and disease severity (16). Neutrophil count and percentage were higher in non-survival patients compared to survival patients. In contrast to the decrease in lymphocyte percentage, the increase in neutrophil percentage was found to be related to mortality. It was seen that the risk of intensive care mortality decreased by $24.5 \%$ 
Table 2. Logistic Regression Model for 28-day intensive care mortality of laboratory parameters and disease scores

\begin{tabular}{|c|c|c|c|c|c|c|}
\hline & & \multicolumn{5}{|c|}{ 28-DAY MORTALITY } \\
\hline & \multicolumn{3}{|c|}{ Univariate analysis $(n=101)$} & \multicolumn{2}{|c|}{ Multivariate Analysis } & \\
\hline & $\begin{array}{l}\text { Mortality } \\
(n=55)\end{array}$ & Survived $(n=46)$ & $P$ & $\begin{array}{l}\text { OR (\%95 } \\
\quad \mathrm{Cl})\end{array}$ & $P$ & \\
\hline \multicolumn{2}{|l|}{ Leucocyte Count, mean (SD), x 10\%/L } & $12.6(6.01)$ & $10.3(3.31)$ & 0.015 & & \\
\hline \multicolumn{2}{|l|}{ Lymphocyte, median (IQR), x 109/L } & $0.80(0.47-1.16)$ & $0.96(0.79-1.18)$ & 0.038 & & 0.108 \\
\hline \multicolumn{2}{|l|}{ Neutrophil, mean (SD), x 109/L } & $11.96(6.07)$ & $8.97(4.18)$ & 0.088 & & \\
\hline \multicolumn{2}{|l|}{ Platelet, median (IQR) x 109/L } & $188.5(144-310.7)$ & $268.5(204.7-316.5)$ & 0.059 & & \\
\hline \multicolumn{2}{|l|}{ Lymphocyte Percentage, median (IQR), (\%) } & $5.5(3.7-8.9)$ & $7.8(5-10.7)$ & $<0.001$ & $\begin{array}{l}0.436 \\
(0.232- \\
0.818)\end{array}$ & 0.010 \\
\hline \multicolumn{2}{|l|}{ Neutrophil Percentage, median (IQR) (\%) } & $86.8(83.2-90.8)$ & $81.3(76-85.4)$ & 0.001 & & 0.097 \\
\hline \multicolumn{2}{|l|}{ C-Reactive Protein, median (IQR) mg/L } & $209(114.2-278.1)$ & $124(57.9-175.3)$ & 0.006 & & 0.087 \\
\hline \multicolumn{2}{|l|}{ Procalcitonin, median (IQR), ng/mL } & $2.8(1.08-5.47)$ & $0.33(0.13-1.20)$ & $<0.001$ & $\begin{array}{l}1.487 \\
(1.039- \\
2.128)\end{array}$ & 0.030 \\
\hline \multicolumn{2}{|l|}{ Ferritin, median (IQR), ng/mL } & $879(503.5-1490)$ & 499 (196-910) & 0.001 & & 0.339 \\
\hline \multicolumn{2}{|l|}{ D - dimer, median (IQR), ng/mL } & $3.89(2-5.98)$ & $1.90(0.86-3.01)$ & 0.087 & & \\
\hline \multicolumn{2}{|l|}{ Fibrinogen, median (IQR), mg/dL } & $239(95-405)$ & $388(198.5-460)$ & 0.751 & & \\
\hline Troponin, median (IQR), ng/mL & \multicolumn{2}{|c|}{$38(12-402.6)$} & $22.2(7.25-58)$ & 0.379 & & \\
\hline Creatine Kinase, median (IQR) U/L & \multicolumn{2}{|c|}{$215.5(70-334.7)$} & $168(64.2-361.6)$ & 0.008 & & \\
\hline $\begin{array}{l}\text { ProBrain Natriuretic Peptide, } \\
\text { median (IQR) } \\
\mathrm{pg} / \mathrm{mL}\end{array}$ & \multicolumn{2}{|c|}{4562.5 (1792.5-13017.5) } & $750.2(143.3-5405)$ & 0.002 & & \\
\hline $\begin{array}{l}\text { Aspartate Aminotransferase, } \\
\text { median (IQR) U/L }\end{array}$ & \multicolumn{2}{|c|}{$64(47.2-89.5)$} & $47.5(33-59)$ & 0.016 & & 0.653 \\
\hline $\begin{array}{l}\text { Alanine Aminotransferase, } \\
\text { median (IQR) U/L }\end{array}$ & \multicolumn{2}{|c|}{$32(21.5-51.2)$} & $44(27.5-65)$ & 0.279 & & \\
\hline $\begin{array}{l}\text { Lactate Dehydrogenase, } \\
\text { median (IQR) U/L }\end{array}$ & \multicolumn{2}{|c|}{541 (427.2-729) } & 365 (315.7-435.5) & $<0.001$ & $\begin{array}{l}1.015 \\
(1.005- \\
1.025)\end{array}$ & 0.003 \\
\hline SOFA, mean (SD) & \multicolumn{2}{|l|}{$10.1(4)$} & $6.9(3.33)$ & $<0.001$ & & 0.237 \\
\hline $\begin{array}{l}\text { APACHE II (first hospitalization), } \\
\text { median (IQR) }\end{array}$ & \multicolumn{2}{|l|}{$26(20-30)$} & $18(14.2-24.7)$ & 0.007 & & 0.418 \\
\hline $\begin{array}{l}\text { APACHE II (ward discharge), } \\
\text { median (IQR) }\end{array}$ & \multicolumn{2}{|c|}{$56.9(35.2-70)$} & $29(18.2-52.2)$ & 0.025 & & \\
\hline Charles comorbidity score, $n$ & $4(3-6)$ & & $3(1-3.7)$ & 0.004 & $\begin{array}{l}2.936 \\
(1.319- \\
6.535)\end{array}$ & 0.008 \\
\hline
\end{tabular}


in patients diagnosed with COVID-19, with a decrease in neutrophil values. In laboratory analyzes conducted in non-survival cases (25 case series) due to COVID-19, it was found that the last neutrophil value increased significantly in $87.5 \%$ of patients compared to the first value. This suggests that elevating neutrophil levels can be used as an indicator of disease progression ${ }^{(16)}$. High neutrophil values can be considered as indicative of the progression of bacterial superinfection or viral infection to COVID-19 disease.

Non-survival patients' platelet count values were found to be insignificantly lower than those of survival patients. There are many studies in the literature stating that platelet counts of non-survival patients are lower than those of survival patients due to COVID-19 pneumonia.

LDH values were found to be significantly higher in non-survival patients compared to survival patients. The ability to predict 28-day intense mortality of LDH values was found to be high (Table 2 ). The predictive value of $\mathrm{LDH}$ as an indicator of changing glucose metabolism in patients with sepsis was investigated (17). There is evidence in the literature that serum LDH level is slightly associated with mortality. However, it is not clear that a high LDH level is an independent determinant of an unfavorable clinical outcome. More detailed studies are required for the relationship of high LDH levels with lung damage and tissue damage and their potential mechanisms in severe COVID-19 patients.

D-dimer values were insignificantly higher in nonsurvival patients compared to survival patients. The values were high specificity but low sensitivity. However, D-dimer values were not evaluated as an independent parameter related to the risk of death in the univariate analysis of the regression model. Patients with D-dimer levels of $2.0 \mathrm{ng} / \mathrm{mL}$ had a higher mortality rate than patients with values below $2.0 \mathrm{ng} / \mathrm{mL}$, according to a report conducted in Wuhan in January ${ }^{(18)}$. COVID-19 infection occurs with a coagulopathy problem that increases mortality, characterized by procoagulant factors such as fibrinogen and predominantly high D-dimer levels (18). However, there was no such finding in the present study.
When the fibrinogen levels of non-survival patients were compared with those of survival patients, there was no significant difference. Mucha SR et al. described the normal levels of fibrinogen levels as a laboratory finding for COVID-19, although D-dimer levels were increased ${ }^{(19)}$. In a COVID-19 population in which a series of 43 patients were examined, it was found that those with severe disease findings had significantly higher levels of fibrinogen than those with mild disease findings ${ }^{(19)}$.

Ferritin levels in non-survival patients were significantly higher than in survival patients. In a cohort study by Henry BM et al., similarly higher ferritin levels were detected in non-survival patients ${ }^{(20)}$. In another study conducted in China, it was emphasized that following the ferritin levels might be beneficial in recognition of patients who might have mortality ${ }^{(20)}$.

The ProBNP values of non-survival patients were found to be significantly higher compared to survival patients. In the study by Evrim EA et al., NT-ProBNP has been claimed to be a good predictor of the 30-day mortality of pneumonia patients ${ }^{(21)}$. However, in this study, it was determined that ProBNP alone did not have any risk or protective factor in intensive care and 28-day mortality in COVID-19 disease. In a new study examining the relationship between COVID-19 and NT-ProBNP, it was stated that it was an independent indicator for mortality of patients with NT-proBNP values at $>88.64 \mathrm{pg} / \mathrm{mL}^{(22)}$ whether $\mathrm{N}$ terminal pro B type natriuretic peptide (NT-proBNP.

Serum creatinine kinase (CK) values were higher in nonsurvival patients compared to survival patients. Jing Yuan et al. identified a relationship between serum CK levels and SARS-Cov-2 viral mRNA elimination. It was seen that the decrease in serum CK levels and the increase in viral elimination were correlated ${ }^{(23)}$.

AST values were higher in non-survival patients compared to survival patients. However, there was no difference in the more specific ALT values in the liver.

Non-survival patients' SOFA, APACHE II scores, and APACHE II mortality percentage values were found to be significantly higher compared to survival patients. 
These values were compatible with the literature.

In the Charlson Comorbidity Score (CCS), the most common comorbid disease was hypertension, and the second most common disease was diabetes mellitus. CCS was evaluated as the most successful parameter in predicting 28-day intensive care mortality. In a meta-analysis study, similar to our results, it was determined that higher CCS was associated with increased mortality and disease severity in COVID-19 patients, and mortality risk increased by $16 \%$ for each point increase in CCS (24). In another study, it was determined that the increase in the CCS score summarizing the age and burden of comorbid diseases predicts the increase in mortality risk in COVID-19 patients (25). Therefore, in the intensive care follow-up of COVID-19 patients, the effects of laboratory parameters (especially lymphocyte percentage and LDH) as well as the comorbid diseases of patients should be considered.

\section{CONCLUSIONS}

It was seen that high lymphocyte values close to typical values, and low neutrophil values significantly decreased the risk of intensive care mortality in patients diagnosed with COVID-19. CRP, pro-BNP, lymphocyte count, AST, ferritin, and SOFA and APACHE II scores were found to be ineffective in predicting intensive care and 28-day mortality rates.

Percentage of lymphocytes, LDH, and Charlson comorbidity score were evaluated as the most successful parameters for predicting 28-day intensive care mortality. It is recommended to use the mentioned laboratory parameters and CCS as a predictive of 28-day intensive care mortality in COVID-19 disease.

\section{Abbreviations}

COVID-19: The Coronavirus Disease 2019

SQL: Structured Query Language

CRP: C-reactive protein

ALT: Alanine aminotransferase

AST: Aspartate aminotransferase

LDH: Lactate dehydrogenase

PCT: Procalcitonin

SOFA: Sequential Organ Failure Assessment Score

APACHE II: Acute Physiology and Health Assessment
Score

CCS: Charlson Comorbidity Score

ICU: Intensive Care Unit

2019-nCoV: novel Coronavirus strain

US: United States

IQR: Interquartile Range

SD: Standard Deviation

LR: Logistic Regression

OR: Odd's Ratio

$\mathrm{Cl}$ : Confidence Interval

WBC: White Blood Cell

SARS-CoV-2: Severe acute respiratory syndrome coronavirus 2

CK: Creatine Kinase

NT-proBNP: N-terminal pro hormone BNP

Ethics Committee Approval: Non-Invasive Research Ethics Committee approval was obtained from Bakirkoy Dr. Sadi Konuk Training and Research Hospital (04.05.2020/2020-10-22).

Conflict of Interest: The authors declare they have no conflict of interest.

Funding: The authors declared that this study received no financial support.'

Informed Consent: Participants were informed about the study, and written consent was obtained from them. For the patients who were unable to give their consent was obtained from their guardians.

\section{REFERENCES}

1. Li Q, Guan X, Wu P, Wang X, Zhou L, Tong Y, et al. Early Transmission Dynamics in Wuhan, China, of Novel Coronavirus-Infected Pneumonia. N Engl J Med. 2020 Mar 26;382(13):1199-1207.

2. Mo $P$, Xing $Y$, Xiao $Y$, Deng $L$, Zhao $Q$, Wang $H$, et al. Clinical characteristics of refractory COVID-19 pneumonia in Wuhan, China. Clin Infect Dis. 2020 Mar 16:ciaa270. https://doi.org/10.1093/cid/ciaa270

3. WHO Rolling updates on coronavirus disease (COVID-19) https:// www.who.int/emergencies/diseases/novel-coronavirus-2019

4. Onder G, Rezza G, Brusaferro S. Case-Fatality Rate and Characteristics of Patients Dying in Relation to COVID-19 in Italy. JAMA. 2020 May 12;323(18):1775-6. https://doi.org/10.1001/jama.2020.4683

5. CDC COVID-19 Response Team, CDC COVID-19 Response Team, Bialek S, Boundy E, Bowen V, Chow N, vd. Severe Outcomes Among Patients with Coronavirus Disease 2019 (COVID-19) United States, February 12-March 16, 2020. MMWR Morb Mortal Wkly Rep. 2020 Mar 27;69(12):343-6. https://doi.org/10.15585/mmwr.mm6912e2

6. Baud D, Qi X, Nielsen-Saines K, Musso D, Pomar L, Favre G. Real estimates of mortality following COVID-19 infection. Lancet Infect Dis. 2020 Jul;20(7):773. https://doi.org/10.1016/S1473-3099(20)30195-X

7. Cummings MJ, Baldwin MR, Abrams D, Jacobson SD, Meyer BJ, 
Balough EM, Aaron JG, Claassen J, Rabbani LE, Hastie J, Hochman BR, Salazar-Schicchi J, Yip NH, Brodie D, O'Donnell MR. Epidemiology, clinical course, and outcomes of critically ill adults with COVID-19 in New York City: a prospective cohort study. Lancet. 2020 Jun 6;395(10239):1763-1770. https://doi.org/10.1016/S0140-6736(20)31189-2

8. Chen R, Sang L, Jiang M, Yang Z, Jia N, Fu W, Xie J, Guan W, Liang W, Ni Z, Hu Y, Liu L, Shan H, Lei C, Peng Y, Wei L, Liu Y, Hu Y, Peng P, Wang J, Liu J, Chen Z, Li G, Zheng Z, Qiu S, Luo J, Ye C, Zhu S, Zheng J, Zhang N, Li Y, He J, Li J, Li S, Zhong N; Medical Treatment Expert Group for COVID-19. Longitudinal hematologic and immunologic variations associated with the progression of COVID-19 patients in China. J Allergy Clin Immunol. 2020 Jul;146(1):89-100.

https://doi.org/10.1016/j.jaci.2020.05.003

9. Elshazli RM, Toraih EA, Elgaml A, El-Mowafy M, El-Mesery M, Amin MN, Hussein MH, Killackey MT, Fawzy MS, Kandil E. Diagnostic and prognostic value of hematological and immunological markers in COVID-19 infection: A meta-analysis of 6320 patients. PLoS One. 2020 Aug 21;15(8):e0238160 https://doi.org/10.1371/journal.pone.0238160

10. Republic of Turkey Ministry of Health. COVID-19 Guideline. [23 July 2020]; Available from: https://covid19bilgi.saglik.gov.tr/tr/ covid-19-rehberi.html.

11. Wang D, Hu B, Hu C, Zhu F, Liu X, Zhang J, Wang B, Xiang H, Cheng Z, Xiong Y, Zhao Y, Li Y, Wang X, Peng Z. Clinical Characteristics of 138 Hospitalized Patients With 2019 Novel Coronavirus-Infected Pneumonia in Wuhan, China. JAMA. 2020 Mar 17;323(11):10611069. https://doi.org/10.1001/jama.2020.1585

12. Matsumoto $H$, Kasai $T$, Sato $A$, Ishiwata $S$, Yatsu $S$, Shitara J, Murata A, Kato T, Suda S, Matsue Y, Hiki M, Takagi A, Daida H. Association between C-reactive protein levels at hospital admission and long-term mortality in patients with acute decompensated heart failure. Heart Vessels. 2019 Dec;34(12):1961-1968. https://doi.org/10.1007/s00380-019-01435-9

13. Chalmers S, Khawaja A, Wieruszewski PM, Gajic O, Odeyemi Y. Diagnosis and treatment of acute pulmonary inflammation in critically ill patients: The role of inflammatory biomarkers. World J Crit Care Med. 2019 Sep 11;8(5):59-71. https://doi.org/10.5492/wjccm.v8.i5.74

14. Deng Y, Liu W, Liu K, Fang YY, Shang J, Zhou L, Wang K, Leng F, Wei S, Chen L, Liu HG. Clinical characteristics of fatal and recovered cases of coronavirus disease 2019 in Wuhan, China: a retrospective study. Chin Med J (Engl). 2020 Jun 5;133(11):1261-1267. https://doi.org/10.1097/CM9.0000000000000824

15. Debuc B, Smadja DM. Is COVID-19 a New Hematologic Disease? Stem Cell Rev Rep. 2020 May 12:1-5. https://doi.org/10.1007/s12015-020-09987-4

16. Guan WJ, Ni ZY, Hu Y, Liang WH, Ou CQ, He JX, Liu L, Shan H, Lei
CL, Hui DSC, Du B, Li LJ, Zeng G, Yuen KY, Chen RC, Tang CL, Wang T, Chen PY, Xiang J, Li SY, Wang JL, Liang ZJ, Peng YX, Wei L, Liu Y, Hu YH, Peng P, Wang JM, Liu JY, Chen Z, Li G, Zheng ZJ, Qiu SQ, Luo J, Ye CJ, Zhu SY, Zhong NS; China Medical Treatment Expert Group for Covid-19. Clinical Characteristics of Coronavirus Disease 2019 in China. N Engl J Med. 2020 Apr 30;382(18):17081720. https://doi.org/10.1101/2020.02.06.20020974

17. Lu J, Wei Z, Jiang H, Cheng L, Chen Q, Chen M, Yan J, Sun Z. Lactate dehydrogenase is associated with 28-day mortality in patients with sepsis: a retrospective observational study. J Surg Res. 2018 Aug;228:314-321. https://doi.org/10.1016/j.jss.2018.03.035

18. Zhang L, Yan X, Fan Q, Liu H, Liu X, Liu Z, Zhang Z. D-dimer levels on admission to predict in-hospital mortality in patients with Covid-19. J Thromb Haemost. 2020 Jun;18(6):1324-1329. doi: 10.1111/jth.14859. https://doi.org/10.1111/jth.14859

19. Mucha SR, Dugar S, McCrae K, Joseph D, Bartholomew J, Sacha GL, Militello M. Coagulopathy in COVID-19: Manifestations and management. Cleve Clin J Med. 2020 Jul 31;87(8):461-468. https://doi.org/10.3949/ccjm.87a.ccc024

20. Henry BM, de Oliveira MHS, Benoit S, Plebani M, Lippi G. Hematologic, biochemical and immune biomarker abnormalities associated with severe illness and mortality in coronavirus disease 2019 (COVID-19): a meta-analysis. Clin Chem Lab Med. 2020 Jun 25;58(7):1021-1028. https://doi.org/10.1515/cclm-2020-0369

21. Akpınar EE, Hoşgün D, Akpınar S, Ateş C, Baha A, Gülensoy ES, Ogan N. Do N-terminal pro-brain natriuretic peptide levels determine the prognosis of community acquired pneumonia? J Bras Pneumol. 2019 Aug 12;45(4):e20180417. https://doi.org/10.1590/1806-3713/e20180417

22. Gao L, Jiang D, Wen XS, Cheng XC, Sun M, He B, You LN, Lei P, Tan XW, Qin S, Cai GQ, Zhang DY. Prognostic value of NT-proBNP in patients with severe COVID-19. Respir Res. 2020 Apr 15;21(1):83. https://doi.org/10.1186/s12931-020-01352-w

23. Yuan J, Zou R, Zeng L, Kou S, Lan J, Li X, Liang Y, Ding X, Tan G, Tang $S$, Liu L, Liu Y, Pan Y, Wang Z. The correlation between viral clearance and biochemical outcomes of 94 COVID-19 infected discharged patients. Inflamm Res. 2020 Jun;69(6):599-606. https://doi.org/10.1007/s00011-020-01342-0

24. Tuty Kuswardhani RA, Henrina J, Pranata R, Anthonius Lim M, Lawrensia S, Suastika K. Charlson comorbidity index and a composite of poor outcomes in COVID-19 patients: A systematic review and meta-analysis. Diabetes Metab Syndr. 2020;14(6):2103-2109.

25. Iaccarino G, Grassi G, Borghi C, Ferri C, Salvetti M, Volpe M, et al. Age and Multimorbidity Predict Death Among COVID-19 Patients: Results of the SARS-RAS Study of the Italian Society of Hypertension. Hypertension. 2020;76(2):366-372. 